\title{
Content of nutritionally important components in mare milk fat
}

\author{
Pavlína Navrátilová*, Jan Pospišil, Ivana Borkovcová, \\ Lenka Kaniová, Sandra Dluhošová, Simona Horáková
}

\begin{abstract}
University of Veterinary and Pharmaceutical Sciences Brno, Faculty of Veterinary Hygiene and Ecology, Department of Milk Hygiene and Technology, Palackého tr. 1946/1, CZ-612 42 Brno, Czech Republic *Corresponding author/Dopisni autor: Phone/Tel: +420 541562716, E-mail: navratilovap@vfu.cz
\end{abstract}

\section{Abstract}

Characteristic properties that make mare milk interesting from a nutritional point of view, include the different composition and properties of milk fat. The aim of this study was to determine the total fat content, cholesterol content, percentage of saturated fatty acids (SFA), monounsaturated (MUFA) and polyunsaturated fatty acids (PUFA), content of n-3 and n-6 PUFA, linoleic acid (LA) and alpha-linolenic acid (ALA) in milk samples obtained from 10 mares during the first 6 months of lactation. Content of fat $(9.79 \pm 7.04 \mathrm{~g} / \mathrm{L})$ and cholesterol $(27.47 \pm 14.72 \mathrm{mg} / \mathrm{L})$ in mare milk was lower than in human and bovine milk. From the nutritional point of view, the higher percentage of unsaturated FA (55\%) was significant, while MUFA represented $34 \%$ and PUFA $21 \%$ of that. The proportion of essential fatty acids of LA and ALA was $12.3 \%$ and $3.9 \%$ respectively. The ratio of n-6/n-3 PUFA was the most balanced in the first half of lactation. The influence of breed, stage of lactation and feed was statistically evaluated. The milk fat composition exhibited relatively large variability depending on these factors. Milk was richer in nutritionally important ingredients during the first three months of lactation.

\section{Key words: mare milk; fat composition; cholesterol; fatty acids; nutritional significance}

\section{Introduction}

Despite the negligible worldwide importance of horses for the production of milk for human nutrition, according to current estimates, about 30 million people in the world regularly consume mare milk and this number is steadily growing. Mare milk is an important and traditional food of animal origin in the steppe regions of Central Asia where it is mainly consumed as a fermented milk drink - named Koumiss (Doreau and Martin-Roset, 2003; Park et al., 2006). In countries with traditional mare milk and Koumiss production, their beneficial effects on human health have been known for centuries and they are used in therapy of many diseases (Park et al., 2006; Pieszka et al., 2016). In recent years, interest in mare milk has experienced renaissance in some European countries (Netherlands, Belgium, Norway, and France). Mare milk is used for the production of dairy products, in the cosmetics industry, and for the manufacture of food supplements. Due to the differences in its production and methods of obtaining, however, it is becoming a more luxurious product (Park et al., 2006). In industrialized 
countries, there is a growing interest in functional foods, which can positively affect human health and prevent the emergence of civilization diseases in addition to their nutritional function.

Recently, research on the composition of milk fat has been highlighted by the issue of its health significance in connection with conclusions of some scientific papers on the effects of saturated, monounsaturated and polyunsaturated fatty acids, and cholesterol on human health and the development of civilization diseases. A particular interest is focused on the physiologically significant PUFA (linoleic acid, alpha-linolenic acid, and conjugated linoleic acid). Characteristic properties that make mare milk interesting from a nutritional point of view include the different composition and properties of milk fat (Park et al., 2006, Uniacke-Lowe et al., 2010; Pieszka et al., 2016). Mare milk is characterized by low cholesterol and a high content of polyunsaturated fatty acids. Lipids contain less triacylglycerols (81\%), compared to cows' and mother's milk (97\% and $98 \%$ respectively), and have a different structure, which affects lipase activity and fat absorption in the gastrointestinal tract (Malacarne et al., 2002). The milk fat composition of mare milk is interesting from the nutritional point of view due to its higher content of polyunsaturated FA, most of which are the a-linolenic 9,12,15-all-cisC18:3 (ALA) from the n-3 PUFA and linoleic acid 9-cis,12-cisC18:2 (LA) from the n-6 PUFA, which are essential for human organism and positively affect a number of physiological processes in the body. Another essential FA, the conjugated linoleic acid (C18:2 n-7), is known for its anti-carcinogenic and anti-oxidative activity. However, its content in the mare milk is low (Pieszka et al., 2016). Differences in the presence of fatty acids in mare milk compared to ruminants' milk are associated with dietary differences, fatty acid biosynthesis, and digestive processes in the gastrointestinal tract of horses (Doreau and Boulot, 1989). Flax (Linum usitatissimum L.) is a multi-purpose crop. Its seeds containing about 36 to $40 \%$ of oil, have long been used in human and animal diets and in industry as a source of oil. Linseeds are the richest (among crop plants) source of polyunsaturated fatty acids (PUFA) essential in the human diet. Linseed oil was found to contain high levels of linolenic (53.21\%) followed by oleic (18.51\%), and linoleic (17.25\%), while the dominant saturated acids were palmitic (6.58 \%) and stearic (4.43\%) (Popa et al., 2012). No study on the influence of linseed oil on composition of mare milk fat has been published yet.

The aim of the study was to determine selected nutritionally important components of mare milk with a focus on fat content: total fat, cholesterol, saturated fatty acids (SFA), monounsaturated fatty acids (MUFA) and polyunsaturated fatty acids (PUFA), stearic fatty acid, n-3 PUFA, n-6 PUFA, n-6/n-3 PUFA ratio, linoleic (LA) and a-linolenic (ALA) fatty acids. The influence of breed, stage of lactation and feed was statistically evaluated. The effect of the feed composition was monitored in the mares, the feed of some of the mares was enriched with linseed.

\section{Material and methods}

\section{Material}

Samples of mare milk were obtained in 2016 from 10 breeding mares of four breeds (Czech Warm Blood - CWB, Moravian Warm Blood - MWB, Trakehner Horse - TRA, Oldenburger Horse - OLD) foaled in March to May. Samples were obtained manually within 6 months of delivery with the sampling frequency 1 x per month. A total of 60 samples of mare milk were collected and tested. In addition to the breed and stage of lactation, the effect of the feed composition was monitored in the mares. 7 mares were fed with a standard feed dose during lactation. In addition to hay, the standard feed dose contained oats (3-4 kg/day) and complementary feed (3-4 kg/day) with the following composition: wheat bran, malt flower, oats, alfalfa powder, sugar beet pulps, barley, maize, beet molasses, calcium carbonate, sodium chloride, vitamins, and trace elements. 3 mares were fed with hay as well as oats (3-4 kg/day) and supplementary feed (2 kg/ day) containing: oats, barley, alfalfa powder, wheat germs, wheat bran, lysine, dried sugar beet pulps, apple pomace, feed salt, vitamins, trace elements and $1 \mathrm{~kg}$ of probiotic mixture (hydrothermally treated flaked maize, extruded wheat, alfalfa powder, wheat bran, hydrothermally treated flaked barley, 
apple pomace, beet molasses, sugar beet pulps, malt flower, grape pomace, whey, rice bran, linseed) and that was enriched with $0.1 \mathrm{~kg} /$ day linseed. Milk samples were obtained from mares in two farms in the Southmoravian region. After milking, the samples were cooled to $4-6{ }^{\circ} \mathrm{C}$, transported and stored at this temperature until the examination. Unless examined within 48 hours from milking, the milk samples were frozen to $-18{ }^{\circ} \mathrm{C}$ and stored at this temperature until the examination.

\section{Methods}

\section{Determination of cholesterol}

Total cholesterol was determined after it had been released from the ester bonds by alkaline hydrolysis (saponification) and extraction of the un-saponifiable portion into a non-polar solvent by reverse phase liquid chromatography.

\section{SAMPLE PREPARATION}

To $1 \mathrm{~mL}$ of milk about $0.1 \mathrm{~g}$ of ascorbic acid and hydroquinone were added, as well as $10 \mathrm{~mL}$ of methanolic $\mathrm{KOH}$ ( 1 part of $10 \mathrm{~mol} / \mathrm{L} \mathrm{KOH}+9$ parts of methanol) and saponified at $60^{\circ} \mathrm{C}$ under reflux for 30 minutes. After cooling, $5 \mathrm{~mL}$ of deionized water and $10 \mathrm{~mL}$ of hexane as an extraction agent were added and shaken vigorously for 20 minutes. After the layers separated, the maximum hexane fraction was taken, rinsed with water to neutral and dried with anhydrous sodium sulphate. The hexane was evaporated, the residue dissolved in methanol and filtered through the membrane filter for using UHPLC.

\section{CONDITIONS OF UHPLC DETERMINATION}

For the final chromatographic assay, an Acquity BEH C8 reversed phase column, $100 \times 2.1 \mathrm{~mm}$, $1.7 \mu \mathrm{m}$ (Waters, Ireland) was used. The mobile phase was a mixture of methanol and water $(v: v=$ 93:7), flow rate of $0.4 \mathrm{~mL} / \mathrm{min}$. Cholesterol detection was performed in UV region at $205 \mathrm{~nm}$. The evaluation was performed using the calibration curve method.

\section{Detection of fatty acid content}

\section{SAMPLE PREPARATION}

Fatty acids were determined in the form of methyl esters using gas chromatography with flame ionization detection. The fat component was obtained from the milk sample through 2-step centrifugation. In the first step, the milk was centrifuged for 30 minutes at 4193.g RCF and $0{ }^{\circ} \mathrm{C}$. After transfer to microtubes, the centrifuged fat was further centrifuged for 15 minutes at 37733.g RCF at room temperature. $0.100 \mathrm{~g}$ of fat was first subjected to alkaline hydrolysis with methanolic $\mathrm{KOH}$ and, after adjusting the $\mathrm{pH}$ using sulfuric acid, it was further re-esterified. The obtained methyl esters were subsequently extracted into n-hexane. The preparation procedure of methyl esters of fatty acids was based on the ISO 12966-2:2011 standard (2011).

\section{CONDITIONS OF THE METHOD}

Chromatographic separation was carried out using a HP 6890 gas chromatograph (Agilent, USA) on an HP-88 column (Agilent, USA) measuring 100 $\mathrm{m} \times 0.25 \mathrm{~mm} \times 0.20 \mathrm{~mm}$ followed by flame ionization detection (FID). $1 \mu \mathrm{L}$ injection of the sample was performed in 50:1 split ratio by integrated autosampling turret of HP 6890 (Agilent, USA). The carrier gas was helium at a flow rate of $1.2 \mathrm{~mL} / \mathrm{min}$, the total analysis time was $35 \mathrm{~min}$. The temperatures at the injection port and at the detector were 220 and $240{ }^{\circ} \mathrm{C}$, respectively. Identification and quantification of fatty acids was performed by a calibration curve method based on comparison with the FAMQ-005 standard (AccuStandard, New Haven, USA). The original standard was diluted to at least 5 concentration levels, measured and the correlation coefficients for every compound were established (Table 1). Furthermore, single standards of the fatty acid methyl esters (Sigma-Aldrich, USA) were analysed to verify the quantification process. Recovery values of the standards ranged between 97-101\%. Temperature program of the method: initial temperature of $100{ }^{\circ} \mathrm{C}$ was maintained for $4.27 \mathrm{~min}$. Afterwards the temperature was raised to $220^{\circ} \mathrm{C}$ at the rate of $13{ }^{\circ} \mathrm{C} / \mathrm{min}$. Then the heating rate was lowered to $5{ }^{\circ} \mathrm{C} / \mathrm{min}$ until reaching $240{ }^{\circ} \mathrm{C}$. After achieving $240{ }^{\circ} \mathrm{C}$, the temperature was hold for $17.50 \mathrm{~min}$. 
TABLE 1. Standards dilution and correlation coefficients of the calibration curves

\begin{tabular}{|c|c|c|c|c|c|c|c|}
\hline \multirow{2}{*}{$\begin{array}{l}\text { FAMQ-005 compounds } \\
\text { butyric acid ME }\end{array}$} & \multicolumn{6}{|c|}{ Calibration levels - concentration $\mu \mathrm{g} / \mu \mathrm{L}$} & \multirow{2}{*}{$\begin{array}{l}r \\
0.997\end{array}$} \\
\hline & 4 & 20 & 40 & 100 & 200 & 400 & \\
\hline caproic acid ME & / & 20 & 40 & 100 & 200 & 400 & 0.946 \\
\hline caprylic acid ME & / & 20 & 40 & 100 & 200 & 400 & 0.956 \\
\hline capric acid ME & / & 20 & 40 & 100 & 200 & 400 & 0.956 \\
\hline undecanoic acid ME & / & 10 & 20 & 50 & 100 & 200 & 0.996 \\
\hline lauric acid ME & / & 20 & 40 & 100 & 200 & 400 & 0.943 \\
\hline tridecanoic acid ME & / & 10 & 20 & 50 & 100 & 200 & 0.963 \\
\hline myristic acid ME & 4 & 20 & 40 & 100 & 200 & 400 & 0.950 \\
\hline myristoleic acid ME & / & 10 & 20 & 50 & 100 & 200 & 0.975 \\
\hline pentadecanoic acid ME & 2 & 10 & 20 & 50 & 100 & 200 & 0.998 \\
\hline cis-10-pentadecenoic acid ME & / & 10 & 20 & 50 & 100 & 200 & 0.997 \\
\hline palmitic acid ME & 6 & 30 & 60 & 150 & 300 & 600 & 0.995 \\
\hline methyl cis-9-hexadecenoate & / & 10 & 20 & 50 & 100 & 200 & 0.955 \\
\hline heptadecanoic acid ME & 2 & 10 & 20 & 50 & 100 & 200 & 0.997 \\
\hline cis-10-heptadecenoic acid ME & / & 10 & 20 & 50 & 100 & 200 & 0.996 \\
\hline stearic acid ME & 4 & 20 & 40 & 100 & 200 & 400 & 0.952 \\
\hline methyl trans-9-octadecenoate & 2 & 10 & 20 & 50 & 100 & 200 & 0.979 \\
\hline methyl cis-9-octadecenoate & 4 & 20 & 40 & 100 & 200 & 400 & 0.984 \\
\hline methyl linoelaidate & / & 10 & 20 & 50 & 100 & 200 & 0.997 \\
\hline linoleic acid ME & 1 & 10 & 20 & 50 & 100 & 200 & 0,997 \\
\hline arachidic acid ME & 4 & 20 & 40 & 100 & 200 & 400 & 0.994 \\
\hline methyl gamma-linolenate & / & 10 & 20 & 50 & 100 & 200 & 0.997 \\
\hline cis-11-eicosenoic acid ME & / & 10 & 20 & 50 & 100 & 200 & 0.983 \\
\hline linolenic acid $\mathrm{ME}$ & / & 10 & 20 & 50 & 100 & 200 & 0.995 \\
\hline heneicosanoic acid ME & 1 & 10 & 20 & 50 & 100 & 200 & 0.980 \\
\hline methyl cis-11,14-eicosadienoate & 2 & 10 & 20 & 50 & 100 & 200 & 0.901 \\
\hline behenic acid ME & 4 & 20 & 40 & 100 & 200 & 400 & 0.982 \\
\hline methyl cis-8,11,14-eicosatrienoate & / & 10 & 20 & 50 & 100 & 200 & 0.997 \\
\hline erucic acid ME & / & 10 & 20 & 50 & 100 & 200 & 0.997 \\
\hline methyl cis-11,14,17-eicosatrienoate & / & 10 & 20 & 50 & 100 & 200 & 0.997 \\
\hline arachidonic acid ME & / & 20 & 40 & 100 & 200 & 400 & 0.997 \\
\hline tricosanoic acid ME & 1 & 20 & 40 & 100 & 200 & 400 & 0.997 \\
\hline methyl cis-13,16-docosadienoate & / & 10 & 20 & 50 & 100 & 200 & 0.997 \\
\hline lignoceric acid ME & 4 & 20 & 40 & 100 & 200 & 400 & 0.980 \\
\hline cis-5,8,11,14,17-eicosapentaenoic acid ME & / & 10 & 20 & 50 & 100 & 200 & 0.996 \\
\hline methyl cis-15-tetracosenoate & / & 10 & 20 & 50 & 100 & 200 & 0.997 \\
\hline cis-4,7,10,13,16,19-DHA ME & / & 10 & 20 & 50 & 100 & 200 & 0.997 \\
\hline
\end{tabular}

ME: methyl ester; r: correlation coefficient of the calibration curve; DHA: docosahexaenoic acid 


\section{Determination of total fat content}

The content of fat was determined by Gerber method. The non-fat solids are dissolved in concentrated sulphuric acid and the resulting mixture is centrifuged. The percentage of fat is read on a graduated scale on the centrifuge tubes (butyrometers) at a temperature of $65^{\circ} \mathrm{C}$. Amyl alcohol is used to facilitate the separation of fat and aqueous phases (ISO 2446:2008, 2008; James, 1995).

\section{Statistical analysis of data}

The analysis was performed using STATISTICA 13.2 (Dell, Inc., Tulsa, OK, USA) software. A threeway model without interaction was chosen for statistical analysis. Evaluation method:

\section{Independent variables (y):}

SFA, MUFA, PUFA, n-3 PUFA, n-6 PUFA, n-6/n-3 PUFA ratio, stearic acid, ALA, LA, fat [log (fat)], cholesterol

\section{Factors:}

Breed: 4 levels - MWB, CWB, OLD, TRA; Month: (6 levels: 1...6); Feed: (2 levels: Linseed, Standard feed dose - Std.).

Model (tree-way ANOVA, main effects):

$y_{i j k}=\mu+a_{i}+\beta_{j}+\gamma_{k}+\varepsilon_{i j k}$

i levels of factor Breed (MWB, CWB, OLD, TRA)

j levels of factor Month (1..6)

k levels of factor Feed (Linseed, Std.)

$\mathrm{y}_{\mathrm{ijk}}$ value of independent variable (SFA, MUFA, etc.)

on $i^{-{ }^{\text {th }}}$ level of factor Breed, $j^{- \text {th }}$ level of factor

Month and $k_{-}{ }^{\text {th }}$ level of factor Feed

$\mu$ grand mean

$a_{i}$ main effect of $i_{-}{ }^{\text {th }}$ level of factor Breed

$\beta_{j}$ main effect of $j^{- \text {th }}$ level of factor Month

$\gamma_{k}$ main effect of $k^{-{ }^{-t h}}$ level of factor Feed

$\varepsilon_{\mathrm{ijk}}$ random errors; normally distributed N $\left(0 ; \sigma^{2}\right)$

On the basis of the data analysis results, the results of the milk fat content parameter were transformed by means of a logarithmic transformation which ensured the fulfilment of the ANOVA assumptions (homogeneity of scattering, residual normality).

\section{Results and discussion}

\section{Fat content}

Along with proteins, carbohydrates, and alcohol, fats are a major source of energy (E) for the body. Fat facilitates also the absorption of fat-soluble dietary components such as vitamins. Fats and oils are also important sources of essential fatty acids (EFA). High fat diets may decrease insulin-sensitivity and are positively associated with changes in fasting and postprandial factor VII, which may increase cardiovascular risk. The EFSA Panel proposes to set for adults a lower bound of the reference intake range of $20 \mathrm{E} \%$ and an upper bound of 35 E \% (EFSA, 2010).

Mare milk differs from mother's and cows' milk in fat content which is present in significantly lower concentrations with an average reported value of $12.1 \mathrm{~g} / \mathrm{kg}$ (Malacarne et al., 2002). The mean fat content in all tested samples of the present study was $0.98 \pm 0.70 \mathrm{~g} / 100 \mathrm{~mL}$. The fat content values fluctuated in a relatively wide concentration range (minimum value 0.150 , maximum value $3.15 \mathrm{~g} / 100$ $\mathrm{mL})$. Published reports dealing with the composition of mare milk also indicated a considerable range of concentrations of fat: $5-20 \mathrm{~g} / \mathrm{kg}$ (Malacarne et al., 2002), 10-20 g/kg (Doreau and Martin-Roset, 2003), 3-42 g/L (Claeys et al., 2014). Fat content is known to be dependent of feeding. High concentrate diets with low roughage decreases the milk fat content in cows, goats, as well as in mares (Doreau and Martin-Roset, 2003). Based on the statistical analysis, it was found that the fat content is statistically very significantly $(p<0.01)$ affected by the lactation stage, breed, and nutrition (Tables $2 \mathrm{~A}, \mathrm{~B}$ ). Fat values tended to decrease with increasing lactation stages. The fat content in the $6^{\text {th }}$ month of lactation was significantly lower $(p<0.01)$ than the values in the $1^{\text {st }}$ and $3^{\text {rd }}$ months of lactation and significantly lower $(p<0.05)$ than in the $2^{\text {nd }}$ month of lactation. Values in the $2^{\text {nd }}, 4^{\text {th }}$ and $5^{\text {th }}$ months of lactation were significantly lower $(p<0.05)$ than in the $1^{\text {st }}$ month of lactation. The observed values and changes correspond to the described changes in fat content during mares' lactation in review published by Doreau and Martuzzi (2006). According to their opinion, the fat content decreases with continued lactation with mean values of $15-25 \mathrm{~g} / \mathrm{kg}$ at the start of lacta- 
tion and $5-15 \mathrm{~g} / \mathrm{kg}$ in the $6^{\text {th }}$ month of lactation. Pikul and Wójtowski (2008) observed a fat content values in mare milk and noted that with continued lactation the fat content from the $1^{\text {st }}$ to the $5^{\text {th }}$ month of lactation decreased from $20.6 \mathrm{~g} / \mathrm{kg}$ to 10.2 g/kg. Csapó et al. (1995) analysed the fat content in mare milk during the first 45 days of lactation. They did not detect statistically significant differences between breeds in fat content in milk. The highest fat values were determined in colostrum, then the fat content decreased, the $2^{\text {nd }}$ through the $5^{\text {th }}$ day the mean fat content was $21.3 \pm 1.89 \mathrm{~g} / \mathrm{kg}$, and between the $8^{\text {th }}$ through the $45^{\text {th }}$ day of lactation it was $12.5 \pm 4.99 \mathrm{~g} / \mathrm{kg}$.

Contrary to the study by Csapó et al. (1995), significant differences $(p<0.01)$ were found in the fat content of milk among breeds. In the milk of TRA mares, the fat content was significantly lower $(p<0.01)$ than in the milk of CWB mares, MWB mares, and OLD mares. The milk fat content of the OLD mares was significantly higher $(p<0.01)$ than in other breeds (TRA Horse, MWB and CWB). In mares fed by feed enriched with linseed, milk contained significantly higher $(p<0.01)$ milk fat levels.

\section{Cholesterol content}

The EFSA Panel concluded that cholesterol was sufficiently synthesized by the body and is not required in the diet. Cholesterol plays a central role in many biochemical processes. Although there is a positive dose-dependent relationship between the intake of dietary cholesterol and blood LDL cholesterol concentration, the main dietary determinant of blood LDL cholesterol concentrations is saturated fat intake. Furthermore, most dietary cholesterol is obtained from the foods which are also significant sources of dietary SFA, e.g. dairy and meat products. The EFSA Panel decided not to propose a reference value for cholesterol intake beside its conclusion on the intake of SFA (EFSA, 2010).

Another difference in nutritional aspects of mare milk is low cholesterol content. The maximum (75.49 mg/L) and minimum values $(2.81 \mathrm{mg} / \mathrm{L})$ indicate that cholesterol values fluctuated within a wide range of concentrations. Published data on cholesterol content in mare milk in literary reports differ. For example, Pieszka et al. (2016) present a mean cholesterol level of $2.04 \mathrm{mg} / \mathrm{L}$, whereas
Claeys et al. (2014) report 50-88 mg/L. The cholesterol content in milk can be affected by a number of factors. The study showed a statistically significant influence $(p<0.05)$ of the lactation stage and a statistically very significant influence $(p<0.01)$ of nutrition on the cholesterol content (Tables 1, 2 A). Significantly higher $(p<0.01)$ cholesterol content was determined in milk of mares whose feed contained the addition of linseed. During lactation after the second and third month values increased, cholesterol levels tended to decrease (quadratically) with the increasing lactation stage. Significantly higher cholesterol levels $(p<0.05)$ were in the $2^{\text {nd }}$ and $3^{\text {rd }}$ months compared to the $6^{\text {th }}$ month of lactation. Statistical analysis showed that cholesterol was in the strongest direct relationship to fat $(r=0.70)$. Pikul and Wójtowski (2008) found a significantly higher $(p<0.05)$ cholesterol content in colostrum compared to milk and a statistically very significant $(p<0.01)$ effect of lactation on cholesterol reduction. The cholesterol content in milk obtained during the $5^{\text {th }}$ month of lactation $(47.0 \pm 6.4 \mathrm{mg} / \mathrm{L})$ was 2 times lower than that in the milk obtained in the $1^{\text {st }}$ month of lactation $(97.5 \pm 6.4 \mathrm{mg} / \mathrm{L})$.

\section{FA representation}

Compared to ruminants' milk, fat of mare milk is significantly different in terms of fatty acid composition, in particular in the presence of PUFA and SFA. As reported in literary sources, mare milk contains 37.5-55.8 \% SFA, 18.9-36.2 \% MUFA and 12.8-51.3 \% PUFA, unlike mother's milk (39.4-45 \% SFA, 33.2-45.1 \% MUFA, 8.1-19.1 \% PUFA) and cows' milk (55.7-72.8 \% SFA, 22.7-30.3 \% MUFA, 2.4-6.3 \% PUFA) (Claeys et al., 2014). The mean representation of SFA, MUFA and PUFA in analysed samples is summarized in Tables $2 \mathrm{~A}$ and 2 B. The mean total sum of SFA in the samples tested did not exceed $45 \%(44.83 \pm 4.97 \%)$. A similar result was published by Pikul and Wójtowski (2008), the percentage of SFA in samples obtained during 5 months of lactation was approximately $45 \%$. Markiewicz-Keszycka et al. (2014) found a slightly higher SFA portion of $49 \pm 3.37 \%$ in samples of late-lactation mare milk. The study published by Pietrzak-Fiećko et al. (2013) confirmed that fatty acid composition was determined by the period of lactation and breed of the mares. 
Stearic acid had the smallest effects on blood HDL

SFA are synthesized by the body and are not required in the diet. The most prevailing SFA in the diet are lauric acid (12:0), myristic acid (14:0), palmitic acid (16:0) and stearic acid (18:0). There is a wide consensus that a mixture of SFA increases blood total, LDL and HDL cholesterol concentrations relative to carbohydrates. As a consequence, the total to HDL cholesterol ratio does not change. A mixture of dietary SFA also decreased fasting triacylglycerol concentrations. Individual SFA have different effects on the concentration of plasma lipoprotein cholesterol fractions. Lauric, myristic and palmitic acid raise blood total and LDL cholesterol concentrations. cholesterol concentrations. Dietary SFA are provided by all fats and oils, which are also important sources of essential FA. Furthermore, a significant proportion of dietary SFA is obtained from animal foods that are also important sources of vitamins and minerals. Thus, there is a limit to which the intake of SFA can be lowered without compromising adequacy of intake of essential nutrients and this will vary between populations depending on prevailing patterns of food intake. The EFSA Panel concludes that SFA intake should be as low as possible within the context of nutritionally adequate diet. The WHO/FAO set population nutrient intake goals for SFA at $<10 \mathrm{E} \%$ (EFSA, 2010).

TABLE 2 A. Evaluation of statistical significance of factors for individual parameters

\begin{tabular}{|c|c|c|c|c|c|c|c|c|c|c|c|}
\hline \multirow{3}{*}{ 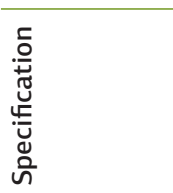 } & \multirow{3}{*}{ 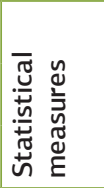 } & \multicolumn{10}{|c|}{ Experimental factors } \\
\hline & & \multicolumn{4}{|l|}{ Breed } & \multicolumn{6}{|c|}{ Month of lactation } \\
\hline & & MWB & CWB & OLD & TRA & 1 & 2 & 3 & 4 & 5 & 6 \\
\hline \multirow{2}{*}{$\begin{array}{l}\text { Log Fat } \\
\text { g/100 mL }\end{array}$} & Mean & $-0.10^{A}$ & $-0.09^{A}$ & $0.27^{\mathrm{B}}$ & $-0.38^{c}$ & $0.13^{\mathrm{Ab}}$ & $-0.13^{\mathrm{ABa}}$ & $-0.01^{\mathrm{Aabc}}$ & $-0.16^{\mathrm{ABac}}$ & $-0.16^{\mathrm{ABac}}$ & $-0.38^{\mathrm{Bbc}}$ \\
\hline & SD & 0.29 & 0.23 & 0.18 & 0.32 & 0.22 & 0.32 & 0.27 & 0.31 & 0.32 & 0.28 \\
\hline \multirow{2}{*}{$\begin{array}{l}\text { Cholesterol } \\
\mathrm{mg} / \mathrm{L}\end{array}$} & Mean & 26.99 & 27.30 & 45.38 & 19.74 & $29.26^{\mathrm{ab}}$ & $34.77^{a}$ & $34.82^{\mathrm{a}}$ & $25.45^{\mathrm{ab}}$ & $22.39^{\mathrm{ab}}$ & $18.13^{b}$ \\
\hline & SD & 11.30 & 14.71 & 18.10 & 13.09 & 15.42 & 18.87 & 14.58 & 11.99 & 10.14 & 10.70 \\
\hline \multirow[t]{2}{*}{ SFA \% } & Mean & 44.38 & 45.32 & 45.15 & 44.78 & $42.55^{\text {ABab }}$ & $39.78^{\mathrm{Aab}}$ & $42.05^{\mathrm{ABab}}$ & $45.20^{\text {BCab }}$ & $48.55^{\mathrm{CDa}}$ & $53.01^{\mathrm{Db}}$ \\
\hline & SD & 5.71 & 5.02 & 4.56 & 3.94 & 2.40 & 3.58 & 1.71 & 2.12 & 2.43 & 3.82 \\
\hline \multirow[t]{2}{*}{ MUFA \% } & Mean & $33.98^{\mathrm{ab}}$ & $35.34^{\mathrm{ab}}$ & $37.03^{a}$ & $31.93^{b}$ & $35.92^{\mathrm{AB}}$ & $37.38^{A}$ & $37.66^{A}$ & $34.29^{A B}$ & $31.38^{\mathrm{BC}}$ & $27.59^{c}$ \\
\hline & SD & 5.26 & 5.10 & 4.12 & 4.33 & 4.35 & 5.99 & 3.31 & 2.66 & 2.21 & 3.78 \\
\hline \multirow[t]{2}{*}{ PUFA \% } & Mean & $21.55^{\text {Aab }}$ & $20.48^{\mathrm{ABa}}$ & $17.65^{\text {Bab }}$ & $23.21^{\mathrm{Ab}}$ & 21.72 & 23.12 & 20.90 & 20.64 & 20.22 & 19.78 \\
\hline & SD & 4.58 & 2.23 & 1.54 & 1.39 & 3.65 & 4.15 & 2.83 & 3.80 & 3.43 & 2.65 \\
\hline \multirow[t]{2}{*}{$n-3$} & Mean & $7.35^{\mathrm{AB}}$ & $6.98^{\mathrm{AB}}$ & $5.18^{A}$ & $8.79^{B}$ & $8.86^{\mathrm{Aab}}$ & $9.66^{\mathrm{Aab}}$ & $8.29^{\mathrm{Aab}}$ & $7.13^{\mathrm{ABCa}}$ & $4.87^{\mathrm{BCab}}$ & $4.05^{\mathrm{BCb}}$ \\
\hline & SD & 3.64 & 2.03 & 1.89 & 3.10 & 2.76 & 3.14 & 2.62 & 2.35 & 1.47 & 1.15 \\
\hline \multirow[t]{2}{*}{$n-6$} & Mean & 14.15 & 13.50 & 12.47 & 13.74 & $12.87^{\text {Aab }}$ & $13.46^{\mathrm{ABab}}$ & $12.61^{\mathrm{Aa}}$ & $13.51^{\mathrm{ABab}}$ & $14.69^{\mathrm{ABb}}$ & $15.55^{\mathrm{Bab}}$ \\
\hline & SD & 2.25 & 1.41 & 0.69 & 1.96 & 1.51 & 1.50 & 0.76 & 1.98 & 1.89 & 2.18 \\
\hline \multirow{2}{*}{$\begin{array}{l}n-6 / n-3 \\
P U F A\end{array}$} & Mean & $2.28^{\mathrm{ab}}$ & $2.13^{a b}$ & $2.79^{a}$ & $1.74^{b}$ & $1.59^{\mathrm{Aab}}$ & $1.53^{\mathrm{Aab}}$ & $1.69^{\mathrm{Aab}}$ & $2.12^{\mathrm{ABa}}$ & $3.10^{\mathrm{BCb}}$ & $3.78^{\mathrm{cab}}$ \\
\hline & SD & 1.07 & 0.78 & 1.27 & 1.13 & 0.56 & 0.57 & 0.64 & 0.90 & 0.66 & 0.90 \\
\hline \multirow{2}{*}{$\begin{array}{l}\text { Stearic } \\
\text { acid } \\
\%\end{array}$} & Mean & 1.28 & 1.27 & 1.20 & 1.26 & $1.2 \mathrm{O}^{\mathrm{ACa}}$ & $0.92^{\text {Bab }}$ & $1.00^{\mathrm{ABb}}$ & $1.30^{\mathrm{cab}}$ & $1.53^{\mathrm{Dab}}$ & $1.78^{\mathrm{Eab}}$ \\
\hline & SD & 0.32 & 0.29 & 0.50 & 0.29 & 0.09 & 0.10 & 0.15 & 0.15 & 0.15 & 0.24 \\
\hline \multirow[t]{2}{*}{ ALA \% } & Mean & $3.64^{a}$ & $4.20^{b}$ & $4.12^{\mathrm{ab}}$ & $3.59^{a}$ & $4.48^{\mathrm{Aa}}$ & $4.42^{\mathrm{Aa}}$ & $4.20^{\mathrm{Aab}}$ & $3.55^{\mathrm{ABCb}}$ & $3.13^{\mathrm{CBab}}$ & $3.13^{\mathrm{cab}}$ \\
\hline & SD & 0.71 & 0.81 & 1.21 & 0.92 & 0.43 & 0.87 & 0.75 & 0.62 & 0.52 & 0.86 \\
\hline \multirow[t]{2}{*}{ LA \% } & Mean & 12.44 & 12.45 & 11.49 & 12.20 & $13.97^{A}$ & $13.40^{A}$ & $12.68^{A B}$ & $11.66^{\mathrm{BCD}}$ & $10.88^{c}$ & $10.77^{\mathrm{CD}}$ \\
\hline & SD & 1.23 & 1.65 & 2.17 & 1.93 & 0.82 & 1.27 & 0.48 & 0.92 & \begin{tabular}{|l|l|}
1.17 \\
\end{tabular} & 1.68 \\
\hline
\end{tabular}

SFA: sum of saturated fatty acids; MUFA: sum of monounsaturated fatty acids; PUFA: sum of polyunsaturated fatty acids, ALA: alpha-linolenic acid; LA: linoleic acid; Means followed by different letters differ significantly: a,b,c - $p<0.05 ; A, B, C, D, E, F-p<0.01$; mean - arithmetic mean; SD - standard deviation 
TABLE 2 B. Evaluation of statistical significance of factors for individual parameters

\begin{tabular}{|c|c|c|c|c|c|c|c|}
\hline \multirow[t]{3}{*}{ Specification } & \multirow{3}{*}{$\begin{array}{l}\text { Statistical } \\
\text { measures }\end{array}$} & \multirow{2}{*}{\multicolumn{2}{|c|}{$\begin{array}{l}\text { Experimental factor } \\
\text { Feed }\end{array}$}} & \multicolumn{4}{|c|}{ Analysis of variance, $p$} \\
\hline & & & & \multirow[t]{2}{*}{ SEM } & \multirow[t]{2}{*}{ Breed } & \multirow{2}{*}{\begin{tabular}{|l} 
Month of \\
lactation
\end{tabular}} & \multirow[t]{2}{*}{ Feed } \\
\hline & & STD & Linseed & & & & \\
\hline \multirow{2}{*}{$\begin{array}{l}\text { Log Fat } \\
\text { g/100 mL }\end{array}$} & Mean & $-0.24^{A}$ & $0.27^{B}$ & \multirow[t]{2}{*}{0.04} & \multirow[t]{2}{*}{$<0.01$} & \multirow[t]{2}{*}{$<0.01$} & \multirow[t]{2}{*}{$<0.01$} \\
\hline & SD & 0.26 & 0.15 & & & & \\
\hline \multirow{2}{*}{$\begin{array}{l}\text { Cholesterol } \\
\mathrm{mg} / \mathrm{L}\end{array}$} & Mean & $22.96^{A}$ & $42.29^{B}$ & \multirow[t]{2}{*}{1.90} & \multirow[t]{2}{*}{0.07} & \multirow[t]{2}{*}{$<0.05$} & \multirow[t]{2}{*}{$<0.01$} \\
\hline & SD & 11.07 & 15.83 & & & & \\
\hline \multirow[t]{2}{*}{ SFA \% } & Mean & 45.46 & 42.72 & \multirow[t]{2}{*}{0.66} & \multirow[t]{2}{*}{0.54} & \multirow[t]{2}{*}{$<0.01$} & \multirow[t]{2}{*}{0,12} \\
\hline & SD & 5.28 & 3.06 & & & & \\
\hline \multirow[t]{2}{*}{ MUFA \% } & Mean & 34.33 & 34.29 & \multirow[t]{2}{*}{0.67} & \multirow[t]{2}{*}{$<0.01$} & \multirow[t]{2}{*}{$<0.01$} & \multirow[t]{2}{*}{0.97} \\
\hline & SD & 5.29 & 4.28 & & & & \\
\hline \multirow[t]{2}{*}{ PUFA \% } & Mean & $20.49^{A}$ & $23.26^{B}$ & \multirow[t]{2}{*}{0.47} & \multirow[t]{2}{*}{$<0.01$} & \multirow[t]{2}{*}{0.353} & \multirow[t]{2}{*}{$<0.01$} \\
\hline & SD & 2.86 & 4.68 & & & & \\
\hline n-3 PUFA & Mean & $6.80^{\mathrm{A}}$ & $8.90^{\mathrm{B}}$ & 0.41 & $<0.01$ & $<0.01$ & $<0.01$ \\
\hline & SD & 2.90 & 3.09 & & & & \\
\hline n-6 PUFA & Mean & 13.51 & 14.26 & 0.25 & $>0.05$ & $<0.01$ & 0.12 \\
\hline & SD & 1.75 & 2.21 & & & & \\
\hline n-6/n-3 PUFA & Mean & $2.33^{A}$ & $1.73^{B}$ & 0.14 & $<0.01$ & $<0.01$ & $<0.01$ \\
\hline & SD & 1.12 & 0.50 & & & & \\
\hline Stearic acid \% & Mean & $1.31^{\mathrm{A}}$ & $1.10^{B}$ & 0.04 & 0.93 & $<0.01$ & $<0.01$ \\
\hline & SD & 0.32 & 0.24 & & & & \\
\hline ALA \% & Mean & $3.65^{A}$ & $4.50^{B}$ & 0.12 & 0.04 & $<0.01$ & $<0.01$ \\
\hline & SD & 0.84 & 0.63 & & & & \\
\hline LA \% & Mean & $12.04^{\mathrm{A}}$ & $13.14^{\mathrm{B}}$ & 0.21 & $<0.05$ & $<0.01$ & $<0.01$ \\
\hline & SD & 1.56 & 1.49 & & & & \\
\hline
\end{tabular}

SFA: sum of saturated fatty acids; MUFA: sum of monounsaturated fatty acids; PUFA: sum of polyunsaturated fatty acids, ALA: alpha-linolenic acid; LA: linoleic acid; Means followed by different letters differ significantly: a,b,c $p<0.05 ; A, B, C, D$ p $<0.01$; SEM -mean standard error; mean- arithmetic mean; SD - standard deviation

Table 2 A shows that SFA values in milk fat were significantly influenced by the lactation stage $(p<0.01)$. After a slight decrease in the $2^{\text {nd }}$ month, the SFA levels tended to grow (quadratically) with continued lactation. The SFA level in the $6^{\text {th }}$ month was significantly different from the values in all previous months. The SFA level in the $5^{\text {th }}$ month was statistically very significantly $(p<0.01)$ different from all previous values with the exception of the $4^{\text {th }}$ month. SFA value in the $4^{\text {th }}$ month was statistically very different from the value in the $2^{\text {nd }}$ month. The statistically significant influence of the breed and the feed dose (Tables 2 A, B) was not determined ( $p>0.05$ ). In mares whose feed dose was enriched with linseed, the mean SFA found was lower, but the difference was not statistically significant. Statistical analysis demonstrates very strong positive relationships between SFA and n-6/n-3 PUFA ratio $(r=0.71)$ and stearic fatty acid $(r=0.80)$ and a very strong negative relationship between SFA and MUFA ( $r=-0.73$ ). On the contrary, the investigations into fatty acid composition carried out by Pietrzak-Fiećko et. al (2009) demonstrated that the total amount of SFA differed in milk samples of the studied breeds. According to their results, the lowest content of SFA was found in the milk of mares of Wielkopolska breed (37.81\%) whereas the highest concentration was found in milk samples of Polish Cold-Blooded mares (54.95\%).

\section{Stearic acid}

Mare milk differs from ruminants' milk by its low stearic acid content $(1.26 \pm 0.32 \%)$, which was also confirmed by our study. The study confirmed the significant effect $(p<0.01)$ of the lactation stage 
and nutrition on the stearic acid content in milk fat (Tables 2 A, B). During lactation after the second and third month values decrease, parameter levels tended to increase (quadratically) with the increasing lactation stage. The values of the stearic FA percentage were significantly higher $(p<0.01)$ in the $5^{\text {th }}$ and $6^{\text {th }}$ months of lactation than in the previous months, the value in the $4^{\text {th }}$ month was significantly higher $(p<0.01)$ than in the $2^{\text {nd }}$ and $3^{\text {rd }}$ months of lactation. Mares fed by feed containing linseed had significantly lower $(p<0.01)$ stearic acid content.

\section{MUFA}

Of the total amount of fatty acids monitored, the mean content of MUFA was $34.32 \pm 5.04 \%$. The percentage of MUFA in mare milk was lower than in mother's milk but similar to cows' milk (Malacarne et al., 2002). Analysis of the obtained data confirmed a statistically significant influence of the lactation stage and breed $(p<0.01)$ on MUFA content in milk fat (Tables $2 \mathrm{~A}, \mathrm{~B}$ ). After a slight increase until the $3^{\text {rd }}$ month of lactation, the MUFA content had a gradual tendency to decrease (quadratically) until the $6^{\text {th }}$ month of lactation. MUFA level was significantly lower $(p<0.01)$ in the $6^{\text {th }}$ month than in the previous months of lactation except for the $5^{\text {th }}$ month. In the $5^{\text {th }}$ month, the MUFA value significantly differed $(p<0.01)$ from the values in the $2^{\text {nd }}$ and $3^{\text {rd }}$ months. A significantly lower $(p<0.05)$ MUFA content was found in the milk fat of the TRA Horse in contrast to the OLD Horse. No statistically significant effect of the feed enriched with linseed was demonstrated.

Nutritional significance for humans: MUFA originate from both plant and animal derived foods. Cis- MUFA are not nutritionally essential as they can be synthesised from other fatty acids and from carbohydrates and have no known specific role in preventing or promoting diet-related diseases. The EFSA Panel has not set any Dietary Reference Values (DRVs) (EFSA, 2010).

\section{PUFA}

Two PUFA, namely the alpha-linolenic acid (18:3, n-3) (ALA) and linoleic acid (18:2, n-6) (LA) are essential to humans and must be provided in the diet. These fatty acids are also the most abundant PUFA in diet. The essential PUFA and PUFA with 20 or more carbon atoms serve important physiological functions in the organism (EFSA, 2010).

PUFA accounted for $21.14 \pm 3.53 \%$ of the total amount of FA detected, which corresponds to the results of some other studies: $21.33 \pm 2.39 \%$ (Markiewicz-Kęszycka et al., 2014) and 22.10$23.96 \pm 0.75 \%$ (Pikul and Wójtowski, 2008). There was no evidence of increase or decrease in PUFA values depending on the lactation stage ( $p>0.05)$. The statistical analysis demonstrated a significant influence $(p<0.01)$ of the feed dose and breed on the PUFA content in milk fat (Tables 2 A, B). A statistically very significant effect $(p<0.01)$ of feed enriched with linseed to increase the PUFA level in milk fat was confirmed. Statistical analysis showed a very strong positive correlation between PUFA and n-3 PUFA.

\section{n-6 PUFA}

The two essential fatty acids, LA and ALA and their long-chain products (AA, EPA and DHA) play prominent physiological roles in various organs. The EFSA Panel proposes to set an Adequate Intake for linoleic acid of $4 \mathrm{E} \%$. There is a negative dose-dependent relationship between the intake of LA and blood LDL cholesterol concentrations, while this relationship is positive for HDL cholesterol concentrations. LA lowers fasting blood triacylglycerol concentrations when compared to carbohydrates (EFSA, 2010).

No statistically significant influence of the breed or the feed dose was found in the n-6 PUFA percentage (Tables $2 \mathrm{~A}, \mathrm{~B}$ ). After the deviation in the $2^{\text {nd }}$ month of lactation, parameter levels tended to increase (quadratically) with the increasing lactation stage. A significantly higher proportion $(p<0.01)$ of $n-6$ PUFA was found in milk fat in the $6^{\text {th }}$ month in contrast to the $1^{\text {st }}$ and $3^{\text {rd }}$ months of lactation and significantly higher proportion $(p<0.05)$ in $5^{\text {th }}$ than in the $3^{\text {rd }}$ month. Pikul and Wójtowski (2008) found a decreasing n-6 PUFA level from the $1^{\text {st }}$ month $(18.64 \pm 0.49 \%)$ to the $5^{\text {th }}$ month of lactation (15.73 $\pm 0.49 \%)$. As published in the literature, the milk fat content of mare milk is also nutritionally interesting due to the essential LA and ALA (Malacarne et al., 2002). The mean proportion of $L A$ from total $F A$ in all tested samples 
was $12.29 \pm 1.60 \%$. As shown by statistical analysis (Tables $2 \mathrm{~A}, \mathrm{~B}$ ), the LA content was significantly $(p<0.01)$ influenced by the lactation stage as well as by the feed $(p<0.01)$. The proportion of LA was decreasing with continuing lactation, LA decreased by $0.66 \%$ on average each month. The LA content was significantly lower $(p<0.01)$ in the $5^{\text {th }}$ and $6^{\text {th }}$ months than in the first three months of lactation. A significantly higher proportion of $L A(p<0.01)$ was detected in the milk of mares fed with the addition of linseed in the feed.

\section{n-3 PUFA}

ALA cannot be synthesised by the body, thus it is considered to be an EFA. The EFSA Panel proposes to set an Adequate Intake for ALA of $0.5 \mathrm{E} \%$. The human body can synthesise eicosapentaenoic acid (EPA) and docosahexaenoic acid (DHA) from ALA. Intervention studies have demonstrated beneficial effects of n-3 LCPUFA on recognised cardiovascular risk factors, such as a reduction of plasma triacylglycerol concentrations, platelet aggregation, and blood pressure. These effects were observed at intakes $\geq 1$ g per day (EFSA, 2010).

The $\mathrm{n}-3$ polysaturated fatty acids content was significantly influenced by the lactation stage, breed and nutrition (Tables $2 \mathrm{~A}, \mathrm{~B}$ ). The percentage of n-3 PUFA slightly increased at the beginning of lactation (up to the $2^{\text {nd }}$ month) and then demonstrated a downward trend with continuing lactation. The trend of the linear decline was so strong that, from a statistical point of view, the slightly lower value in the first month did not suppress the overall trend of the linear decline. Value of n-3 PUFA declined by $0.99 \%$ on average each month. The n-3 PUFA content in the $5^{\text {th }}$ and $6^{\text {th }}$ months of lactation was statistically very significantly lower $(p<0.01)$ compared to the first half of lactation (months 1, 2, 3). Significantly lower $n-3$ PUFA content $(p<0.05)$ was demonstrated in the $6^{\text {th }}$ month compared to the $4^{\text {th }}$ month. The breed influence on the proportion of $n-3$ PUFA was recorded. Proportion of n-3 PUFA was statistically very significantly higher $(p<0.01)$ in TRA Horse than in the OLD Horse. Mares with feed dose enriched with linseed had significantly higher $(p<0.01)$ proportion of $n-3$ PUFA in milk fat. The proportion of $n-3$ PUFA was in a very strong negative correlation ( $r=-0.86$ ) with the ratio of $n-6 / n-3$ PUFA.
The values of the n-3 PUFA percentage are in contradiction with the values presented by Pikul and Wójtowski (2008). According to their findings, the n-3 PUFA from the $3^{\text {rd }}$ to the $5^{\text {th }}$ month increased up to $7.62 \pm 0.39 \%$. The mean ALA percentage $(3.85 \pm 0.87 \%)$ of the monitored FA over the reference period was lower than LA (12.29 $1.6 \%)$. A significant influence $(p<0.01)$ of the lactation stage and nutrition on ALA level and a statistically significant $(p<0.05)$ influence of the breed was found. In mares whose feed dose was enriched with linseed, ALA percentage was significantly higher $(p<0.01)$. A significantly higher proportion of ALA $(p<0.05)$ was recorded in the milk fat of the CWB as compared to the MWB and TRA Horse. The proportion of ALA during lactation demonstrated the same trend as $\llcorner A$, gradually decreasing values with continuing lactation, ALA decreased each month by an average of $0.3 \%$. Statistically significant differences $(p<0.01)$ in ALA percentage were found similarly to $L A$ between the $5^{\text {th }}$ and $6^{\text {th }}$ months of lactation and the first three months of lactation, which was also observed $(p<0.01)$ between the $4^{\text {th }}$ month and the $1^{\text {st }}$ and $2^{\text {nd }}$ months of lactation. Published data on the percentage of these essential FA vary. The results are in line with the data published by $\mathrm{Pi}$ kul and Wójtowski (2008), who also determined a higher proportion of $L A$ and, on the other hand, a lower proportion of ALA. In their study, statistically significant effect of continued lactation from the $1^{\text {st }}$ to the $5^{\text {th }}$ month $(p<0.05)$ was recorded for both essential FA (LA and ALA). According to their published results, LA was $17.95 \%$ of the total FA in the first month and it significantly decreased during the following months, reaching $15.5 \%$ in the $5^{\text {th }}$ month. ALA percentage increased from the mean of $5.13 \%$ it the first three months to $7.5 \%$ in the fifth month. In our study, the average proportion of LA and ALA in the first month was 13.965 and $4.483 \%$, while in the sixth month 10.766 and $3.131 \%$. Therefore, ALA percentage was decreasing during lactation. Statistical analysis demonstrates a strong positive correlation between LA and ALA ( $r=0.70)$.

Markiewicz-Keszycka et al. (2014) reported in a short summary that LA and ALA were the most represented FA of the PUFA group in mare milk in late lactation. According to their data, among the polyunsaturated FA, ALA had a prevalence of $17.51 \pm 3.03 \mathrm{~g} / 100 \mathrm{~g}$ of fat, while the content of LA 
was lower, specifically $3.81 \pm 1.11 \mathrm{~g} / 100 \mathrm{~g}$ of fat. In another study published by a group of authors lead by Csapó (1995), the LA value between the $8^{\text {th }}$ through the $45^{\text {th }}$ day of lactation achieved $7.53 \pm 1.47 \%$, ALA values were higher by $20.12 \pm 4.12 \%$. These authors argued that mare milk in the $45^{\text {th }}$ day of lactation contained 4.9 times more linoleic acid and 224 times more alpha-linolenic fatty acid compared to cows' milk. Malacarne et al. (2002) focused on the nutritional value of mare milk in terms of the content and composition of proteins and milk fat. The mean LA value of the total FA content in mare milk reported in their study reached $9.6 \%$ (5.1-15.5 \%), mean ALA $9.4 \%$ (2.8-15.7\%). The source of these essential fatty acids for horses is feed - LA is present at higher concentrations in concentrated feed, ALA in green forage (Doreau and Martin-Roset, 2003). Based on both, the scientific evidence and conceptual limitations, there is no compelling scientific rationale for the recommendation of a specific ratio of $n-6 / n-3$ PUFA or $L A$ to ALA (WHO, 2008).

\section{Ratio of $n-6 / n-3$ PUFA}

The value of the $n-6 / n-3$ PUFA ratio was significantly $(p<0.01)$ affected by breed, nutrition as well as lactation. The mean value $(2.19 \pm 1.03)$ for the $6^{\text {th }}$ month reference period is within the range of 0.3-3.5 which is reported by Claeys et al. (2014). The most favourable (most balanced) ratio was in the first half of lactation (1.53-1.59). After a slight decrease in the $2^{\text {nd }}$ month, ratio values tended to increase (quadratically) with the increasing lactation stage. In contrast, Pikul and Wójtowski (2008) found a statistically significant decrease in the ratio of $n-6 / n-3$ PUFA during the 5-month lactation from 3.55 in the $1^{\text {st }}$ month of lactation to 2.06 in $5^{\text {th }}$ month of lactation. They believe that the main reason is the change in LA and ALA concentrations. $L A$ and ALA belonged to the most abundant polyunsaturated FA in our study, so we can agree with the statement that their content also significantly affects the value of the $n-6 / n-3$ PUFA ratio. The value of the ratio in the $6^{\text {th }}$ month was statistically very different $(p<0.01)$ from the values in all previous months except for the $5^{\text {th }}$ month. The ratio of $n-6 / n-3$ PUFA in the $5^{\text {th }}$ month of lactation was significantly $(p<0.01)$ different from the values in all previous months of lactation. The value of the ratio was significantly lower $(p<0.05)$ in the TRA Horse than in the OLD Horse. Mares fed with feed enriched with linseed had a significantly lower $(p<0.01)$ mean ratio than other mares $(1.82 \times 2.53)$.

\section{Conclusions}

The study confirmed that the milk fat composition of mare milk, which is also a component of human nutrition, can be quite variable depending on a number of factors - the stage of lactation, nutrition, as well as breed. The breed proved to be a statistically significant factor influencing 6 parameters (MUFA, PUFA, n-3 PUFA, n-6/n-3 PUFA ratio, ALA, fat). The lactation stage had a statistically significant effect on all parameters except PUFA. On the basis of the results obtained, it can be summarized that mare milk is richer in nutritionally important components during the first three months of lactation. The effect of nutrition (feed dose enriched with linseed $x$ feed without the linseed) was not statistically significant in SFA, MUFA and n-6 PUFA, while the parameters of PUFA, n-3 PUFA, ALA, LA, log (fat), and cholesterol reached statistically significantly higher values in mares with a feed dose enriched with linseed.

\section{Acknowledgments}

The work was created with the financial support of the project IGA 203/2016/FVHE VFU Brno. Our appreciation also belongs to Kubíková T. and Iwanuszková J., university students, for their assistance in chemical analyses of samples. 


\section{Sadržaj nutritivno važnih sastojaka u mliječnoj masti mlijeka kobile}

\section{Sažetak}

Raznolik sastav i svojstva mliječne masti čine mlijeko kobile zanimljivim s prehrambene točke gledišta. Cilj ove studije bio je utvrditi ukupan sadržaj masti, sadržaj kolesterola, postotak zasićenih masnih kiselina (SFA), jednostruko (MUFA) i višestruko nezasićenih masnih kiselina (PUFA), sadržaj n-3 i n-6 nezasićenih masnih kiselina, linolne kiseline (LA) i alfa-linolenske kiselina (ALA) u uzorcima mlijeka dobivenih od 10 kobila tijekom prvih 6 mjeseci laktacije. Sadržaj masti $(9,79 \pm 7,04$ g/L) i kolesterola $(27,47 \pm 14,72 \mathrm{mg} / \mathrm{L})$ u mlijeku kobile bio je manji nego u humanom i kravljem mlijeku. S nutritivnog gledišta, mlijeko kobila ima značajno veći postotak nezasićenih masnih kiselina (55 \%), od čega jednostruko nezasićene (MUFA) čine 34 \%, a višestruko nezasićene (PUFA) $21 \%$. Udio esencijalnih masnih kiselina LA i ALA bio je 12,3 \%, odnosno 3,9 \%. Omjer n-6/n-3 bio je povoljniji u prvoj polovici laktacije. Statistički je ocijenjen utjecaj pasmine, stupnja laktacije i hranidbe pri čemu je vidljivo da sastav mliječne masti pokazuje relativno veliku varijabilnost ovisno o ovim čimbenicima. Mlijeko je nutritivno važnim sastojcima bogatije tijekom prva tri mjeseca laktacije.

\section{Ključne riječi: mlijeko kobile, sastav masti, kolesterol, masne kiseline, nutritivno značenje}

\section{References}

1. Claeys, W.L., Verraes, C., Cardoen, S., De Block, J., Huyghebaert, A., Raes, K., Dewettinck, K., Herman, L. (2014): Consumption of raw or heated milk from different species: An evaluation of the nutritional and potential health benefits. Food Control 42, 188-201. https://doi.org/10.1016/j.foodcont.2014.01.045

2. Csapó, J., Stefler, J., Martin, T.G., Makray, S., Csapó- Kiss, Z. (1995): Composition of Mares' colostrums and milk. Fat content, fatty acids composition and vitamin content. International Dairy Journal 5 (4), 393-402. https://doi.org/10.1016/0958-6946(94)00008-D

3. Doreau, M., Boulot, S. (1989): Recent knowledge on mare milk production: a review. Livestock Production Science 22 (3-4), 213-235. https://doi.org/10.1016/0301-6226(89)90057-2

4. Doreau, M., Martin-Roset, W. (2003): Horse. In H. Roginski (Ed.), Encyclopedia of Dairy Sciences, (1st ed.), (pp. 630-637). London UK: Academic Press.

5. Doreau, M., Martuzzi, F. (2006): Fat content and composition of mare's milk. In N. Miraglia, \& MartinRosset W. (Eds.), Nutrition and feeding of the brood mare. EAAP Publication. No. 120, Wageningen, The Netherlands: Wageningen Academic Publishers, 77-87.

6. EFSA (2010): Scientific Opinion on Dietary Reference Values for fats, including saturated fatty acids, polyunsaturated fatty acids, monounsaturated fatty acids, trans fatty acids, and cholesterol. EFSA Journal [online], 8(3), 25 March 2010 [cit. 24 July 2017]. < https://www.efsa.europa.eu/en/efsajournal/pub/1461>.

7. ISO 2446:2008 (E). (2008): Milk - Determination of fat content. 2nd edition. Geneva: International Organization for Standardization.
8. ISO 12966-2:2011 (2011): Animal and vegetable fats and oils - Gas chromatography of fatty acid methyl esters - Part 2: Preparation of methyl esters of fatty acids. Geneva: International Organization for Standardization.

9. James, C.S. (1995): Experimental procedures-estimation of major food constituents. In Analytical chemistry of foods. Oxford: Chapman \& Hall, 93-95.

10. Malacarne, M., Martuzzi, F., Summer, A., Mariani, P. (2002): Protein and fat composition of mare's milk: some nutritional remarks with reference to human and cow's milk. International Dairy Journal 12 (11), 869-877. https://doi.org/10.1016/S0958-6946(02)00120-6

11. Markiewicz-Kęszycka, M., Wójtowski, J., Gryżak-Runowska, G., Kuczyńska, B., Puppel, K., Krzyżewski, J., Strzałkowska, N., Jóźwik, A., Bagnicka, E. (2014): Concentration of selected fatty acids, fat-soluble vitamins, and b-carotene in late lactation mares' milk. International Dairy Journal 38 (1), 31-36. https://doi.org/10.1016/j.idairyj.2014.04.003

12. Park, Y.W., Zhang, H., Zhang, B., Zhang, L. (2006): Mare milk. In: Y.W. Park, \& G.F.W. Haenlaein (Eds.): Handbook of milk of non-bovine mammals. $1^{\text {st }}$ edition. London UK: Blackwell Publishing Ltd., 275-296.

13. Pieszka, M., Łuszczyński, J., Zamachowska, M., Augustyn, R., Długosz, B. - Hędrzak, M. (2016): Is mare milk an appropriate food for people? - A review. Annals of Animal Science 16 (1), 33-51. https://doi.org/10.1515/aoas-2015-0041

14. Pietrzak-Fiećko, R., Tomczyński, R., Świstowska, A., Borejszo, Z., Kokoszko, E. Smoczyńska, K. (2009): Effect of mare's breed on th fatty acid composition of milk fat. Czech Jornal of Animal Science 54 (9), 403-407. https://www.cabdirect.org/cabdirect/ FullTextPDF/2009/20093296443.pdf 
15. Pietrzak-Fiećko, R., Tomczyński, R., Smoczyński, S. (2013): Effect of lactation period on the fatty acid composition in mares' milk from different breeds. Archiv Tierzucht 56 (33), 335-343.

http://doi.fbn-dummerstorf.de/2013/at56a033.pdf

16. Pikul, J., Wójtowski, J. (2008): Fat and cholesterol content and fatty acid composition of mares' colostrums and milk during five lactation month. Livestock Science 113 (2-3), 285-290 https://doi.org/10.1016/j.livsci.2007.06.005

17. Popa, V.M., Gruia, A., Raba1, D.N., Dumbrava, D., Moldovan, C., Bordean D., Mateescu, C. (2012): Fatty acids composition and oil characteristics of linseed (Linum Usitatissimum L.) from Romania. Journal of Agroalimentary Processes and Technologies 18 (2), 136-140. http://www.journal-of-agroalimentary.ro/admin/ articole/61602L07_Popa_Vol.18(2)_2012.pdf
18. Uniacke-Lowe, T., Huppertz, T., Fox, P.F. (2010): Equine milk proteins: Chemistry, structure and nutritional significance. International Dairy Journal 20 (9), 609-629. https://doi.org/10.1016/j.idairyj.2010.02.007

19. WHO. (2008): Interim Summary of Conclusions and Dietary Recommendations on Total Fat \& Fatty Acids. The Joint FAO/WHO Expert Consultation on Fats and Fatty Acids in Human Nutrition, November 10-14, 2008, WHO HQ, Geneva. http://www.who.int/nutrition/topics/FFA_interim_ recommendations /en/ 